\title{
Preparation, Characterization, and Antibacterial of Staphylococcus aureus Activity of Chitosan from Shell of Snail (Achatina fulica F)
}

\author{
Umarudin $^{1}$, Surahmaida1, Rio Alta ${ }^{2}$, Rizka Surya Ningrum ${ }^{3}$ \\ ${ }^{1}$ Akademi Farmasi Surabaya, Surabaya, East Java, Indonesia \\ ${ }^{2}$ Institut Ilmu Kesehatan Bhakti Wiyata Kediri, Kediri, East Java, Indonesia \\ ${ }^{3}$ Penelitian Biomateril LIPI, Bogor, West Java, Indonesia \\ *Corresponding author: umarsains54@gmail.com
}

\begin{abstract}
The shell of snail contains chitin that can be transformed into chitosan through four stages, which are deproteination, demineralization, depigmentation, and deacetylation. Chitosan can be utilized as an antibacterial agent because it has amine groups. In this research, chitosan that prepared from the snail shell will be analyzed using FT-IR spectroscopy to determine the deacetylation degree (DD). The antibacterial activity test result of Staphylococcus aureus will be carried out on chitosan with various concentrations using in-vitro Kirby Bauer method and will be analyzed using One Way ANOVA with confidence level at $95 \%$. The variations concentration of chitosan used is $300,400,500,600$, and 700 ppm. The result shows that the deacetylation degree of chitosan is $63.09 \%$ and the optimum concentration of chitosan that can inhibit the Staphylococcus aureus bacteria is $500 \mathrm{ppm}$ with diameter inhibition is $34.33 \mathrm{~mm}$.
\end{abstract}

Key Words: antibacterial, chitosan, Kirby Bauer Method, Staphylococcus aureus, snail shell

\section{Introduction}

Snails (Achatina fulica F) are pests in rice fields often used by the community as animal feed. In Indonesia, the average number of snails increases by $7.4 \%$ per year (Ridwanto et al., 2016). Livestock snail is a promising prospect because snail meat is exported to France, Japan, Hong Kong, Netherlands, and the United States. Due to the high snail meat demands it makes snail shells from sewage overflow (Rahmadani et al, 2011). Therefore, an alternative is needed for the use of snail shells (Achatina fulica F). One alternative way to use snail shell waste to have value and power and make it be a product with high economic value through processing, which is carried out by chitosan isolation.

Chitosan on snail shells is done through 4 stages: deproteination, demineralization, and depigmentation obtained by chitin. Chitin is then deacetylation through the process of hydrolysis of bases with strong bases to obtain Chitosan. Determinant quality is categorized from good quality Chitosan or the degree of deacetylation. The magnitude of the deacetylation (DD) degree is strongly influenced by base concentration, temperature, time and repetition during chitosan formation. Therefore, this research conducted a degree of deacetylation (DD) test on the snail shell chitosan (Kusumaningsih, 2004). Chitosan is a unique natural polycationic compound as antibacterial (Liu et al., 2006). On the research Staphylococcus aureus is a bacteria, 
Gram-positive coccus shaped or round (Ray, 2004). The bacteria are resistant to dry conditions and tolerant of the relatively high salt concentration. The characters are the reasons why $S$. aureus can live on human skin or human respiratory epithelial cells and does not cause dangerous diseases. However, it becomes harmful if it enters the skin or blood tissue and causes infection (Bannister et al., 2006; Hogg, 2013; Tortora et al., 2013). Staphylococcus aureus can cause skin diseases such as acne, boils, or sores festering and severe respiratory tract infection (Hogg, 2013). Inappropriate use of antibiotics causes the appearance of Staphylococcus aureus that is resistant to antibiotics, such as Methicillin-Resistant Staphylococcus aureus (MRSA) (Tortora et al., 2013).

In some infection cases, antibiotic use is indispensable, but when excessive use can cause some resistant bacteria due to genetic changes. For example, Staphylococcus aureus is resistant to penicillin, nafcillin, and Vancomycin. Therefore, it is needed to look for another alternative with the utilization of the natural material, biomaterial source, because the use of natural materials is comparatively more acceptable by the human body compared to the synthetic materials. One of the ingredients that have not been utilized optimally is chitosan from snail shells.

Research on chitosan as antibacterial effectiveness is also by Liu Hui et al. (2004) showed that chitosan has antibacterial activity by killing bacteria and damage bacterial cell membranes at concentrations of $0.25 \%$ to $0.5 \%$. Research Liu Nan et al (2006) proved that chitosan spider crab (Maia squinado) as an antibacterial against Escherichia coli at low concentrations (20 ppm) of bacteria can be killed. Goy et al (2015) stated that chitosan was able to inhibition the growth of Staphylococcus aureus and Escherichia coli bacteria at concentrations of 1000-1500 ppm. Komariah (2014), show that the utilization of the extract of chitosan and shrimp shell (Panulirus $s p$ ) small crab attaching is able to inhibit the growth of Staphylococcus aureus at concentrations of $22.5 \%-90 \%$. Islam (2011) shows the utilization of crab shell (Maia squinado) extract chitosan is able to inhibition the growth of Staphylococcus aureus and Escherichia coli in the concentration of 600-1000 ppm. Based on the above research, it is necessary to do further research on the shell of snail chitosan which has not been studied.

The antimicrobial mechanism of chitosan against bacteria occurs through two stages. The first stage is based on the presence of an amine functional groups on chitosan that can form a bond with the cell walls of bacteria and lead to the onset of leakage of intracellular constituents so that bacteria will cause lysis. The second stage is starting with damaging the bacterial cell walls, and chitosan performs intracellular binding, blocks mRNA, and inhibits protein synthesis (Killay, 2013). Therefore, this research was conducted to know the Preparation, Characterization, And Antibacterial of Staphylococcus aureus Activity Of Chitosan From Shell of Snail (Achatina fulica F). 


\section{Material and Method}

The materials needed in this study were shell of snail (Achatina fulica F) obtained from vendors located in Pesantren Kediri East Java, Staphylococcus aureus (VRSA) bacterial colonies obtained from Airlangga University Laboratory, Mueller-Hinton Agar (Oxoid) as an effectiveness test, physiological $\mathrm{NaCl}$, aquadest, 10\% peptone (Oxoid), paper disc (Oxoid), $\mathrm{NaOH}, \mathrm{HCl}, \mathrm{NaOCl}$, ampicillin antibiotics, and paper disc.

The shell of snail contains chitin that can be transformed into chitosan through four stages, which are deproteination, demineralization, depigmentation, and deacetylation (Kusumaningsih, 2004). Chitosan is made through a chitin distillation process using the Knorr method (Salami, 1998) by adding $\mathrm{NaOH} \mathrm{60 \%} \mathrm{at} \mathrm{a} \mathrm{ratio} \mathrm{of} \mathrm{20:} 1$ ( $\mathrm{v} / \mathrm{b}$ ) and refluxing at a temperature of $100-140^{\circ} \mathrm{C}$ for 1 hour. After the cold is filtered and the solids obtained are neutralized with distilled water. Solids are then dried in an oven at $80^{\circ} \mathrm{C}$ for 24 hours and chitosan is ready to be analyzed (Kusumaningsih, 2004). Then chitin and chitosan were analyzed using FT-IR spectroscopy for ensuring that acetyl group in chitin substituted by amina group in chitosan. The substitution percentage of acetyl group with amina group can be calculated through the determination of deacetylation degree (DD) of chitosan using this equation (Baxter et al., 1992):

$$
\mathrm{DD}=100-\left[\left(\mathrm{A}_{1655} / \mathrm{A}_{3450}\right) \times 115\right]
$$

The absorbance on the $1655 \mathrm{~cm}^{-1}$ band $\left(\mathrm{A}_{1655}\right)$ is the absorption of the $\mathrm{N}$-acetyl group while the absorbance on $3450 \mathrm{~cm}^{-1}$ (A3450) is absorption of a hydroxyl group. Hydroxyl group can be used as standard because it has specific absorbance and didn't affect by deacetylation process. They were making Rejuvenation Media, Suspension, and Bacterial Testing. Mueller Hinton Agar (MHA) media was weighed for 6.8 grams and mixed with $200 \mathrm{ml}$ of distilled water in an Erlenmeyer tube then heated until it dissolved and sterilized in an autoclave for 15 minutes at $121^{\circ} \mathrm{C}$. Mueller Hinton Agar (MHA) media was poured into a $25 \mathrm{ml}$ petri dish. Colonies of Staphylococcus aureus bacteria were taken with sterile osseous needles, then implanted into the media to tilt by scraping. Bacteria that had been scratched on the media were incubated in an incubator at $37^{\circ} \mathrm{C}$ for 24 hours. Bacteria that had been incubated in the porch of the colony from the media to tilt using a sterile ose needle were then inserted into the $\mathrm{NaCl}$ Broth media until the turbidity was the same as McFarland's standard. McFarland standard solution 0.5 was equivalent to bacterial cell suspension with a concentration of $1.5 \times 10^{8} \mathrm{CFU} /$ $\mathrm{ml}$. This turbidity was used as a standard bacterial suspension test.

Soaking the disks into their respective concentrations of chitosan with snail shells was done by soaking it with sterile tweezers to take each paper discs and dip it into the chitosan concentrations $(500,600,700 \mathrm{ppm})$. The positive control was used by 
Ampicillin antibiotics $1000 \mathrm{ppm}$ and negative control by sterile aquadest. It was left for 20 minutes until thoroughly absorbed on each disc paper. The activity of chitosan shells (Achatina fulica) on the growth of Staphylococcus aureus bacteria was tested. Inoculated using a sterile swab dipped in an inoculum, reducing the excess inoculum by pressing and rotating the swab firmly on the side of the tube. Worn with a cotton swab throughout the surface of the media, also rub a cotton swab around the edges of the agar surface. The plate after planting was left a few minutes at room temperature closed. Paper discs containing each chitosan dilution were placed on $\mathrm{MH}$ media, which had been inoculated, using sterile tweezers. Then the media was placed in an incubator at $37^{\circ} \mathrm{C}$ for 24 hours. Diameter zones were measured by calipers and recorded in $\mathrm{mm}$, and then the results could be interpreted.

\section{Results and Discussion}

Chitosan can be obtained from the chitin distillation process. Chemically chitosan can be obtained through several stages: deproteination, demineralization, depigmentation, and deacetylation. The process of making chitosan is done by removing the acetyl group using the Hong method. The deproteination stage aims to eliminate the protein contained in the snail shell using $\mathrm{NaOH}$ solution, the solution is used to reduce protein content in the snail shell (Kusumaningsih, 2004). Mineralization is done to remove minerals in the form of calcium carbonate contained in the snail shell. Calcium carbonate is more easily separated compared to protein content, this is because it is only physically bound (Kusumaningsih, 2004). The depigmentation process aims to remove dyes or pigments. Continued distillation of chitin aims to obtain snail shell chitosan.

IR spectroscopic tests on chitosan were carried out to analyze functional groups and the degree of deacetylation of chitosan. Before being analyzed, chitosan samples needed to be initially prepared by using $\mathrm{KBr}$ with a ratio of $1: 10$ (w / w). The selection of $\mathrm{KBr}$ as a place for samples in an analysis by using IR spectroscopy is because $\mathrm{KBr}$ is a substance that can be penetrated by infrared light. Another substance that can be penetrated by infrared light and can be used for sample preparation is $\mathrm{NaCl}$.

The results of IR chitosan test can be seen in Figure 1. Based on the image, it is known that the presence of absorption at wavenumbers $1820-1600 \mathrm{~cm}^{-1}$ indicates the presence of carbonyl groups ( $C=0$ ), where the peak of $1620 \mathrm{~cm}-1$ shows the figure. Wide and strong uptake in the area of $3600 \mathrm{~cm}^{-1}$ to $3300 \mathrm{~cm}^{-1}$ can indicate the presence of $\mathrm{O}-\mathrm{H}$ or $\mathrm{N}-\mathrm{H}$ groups. The presence of an $\mathrm{O}-\mathrm{H}$ group is supported by uptake at wavenumbers 1200-1000 $\mathrm{cm}^{-1}$, which suggests the presence of aliphatic alcohol, which in the image is shown by a peak of $1080 \mathrm{~cm}^{-1}$. The presence of an $\mathrm{N}-\mathrm{H}$ group is also supported by the presence of absorption at wave number $1620 \mathrm{~cm}^{-1}$, which indicates the presence of primary amide (-NH2). Uptake between 3000-2800 cm-1 shows the presence of alkyl C-H (Csp3) groups, which in the figure are shown by peaks of $2924 \mathrm{~cm}^{-}$ 
1 and $2854 \mathrm{~cm}^{-1}$. This is supported by the absorption at $1481 \mathrm{~cm}^{-1}$ wave number which indicates the presence of a methylene group $\left(-\mathrm{CH}_{2}\right)$.

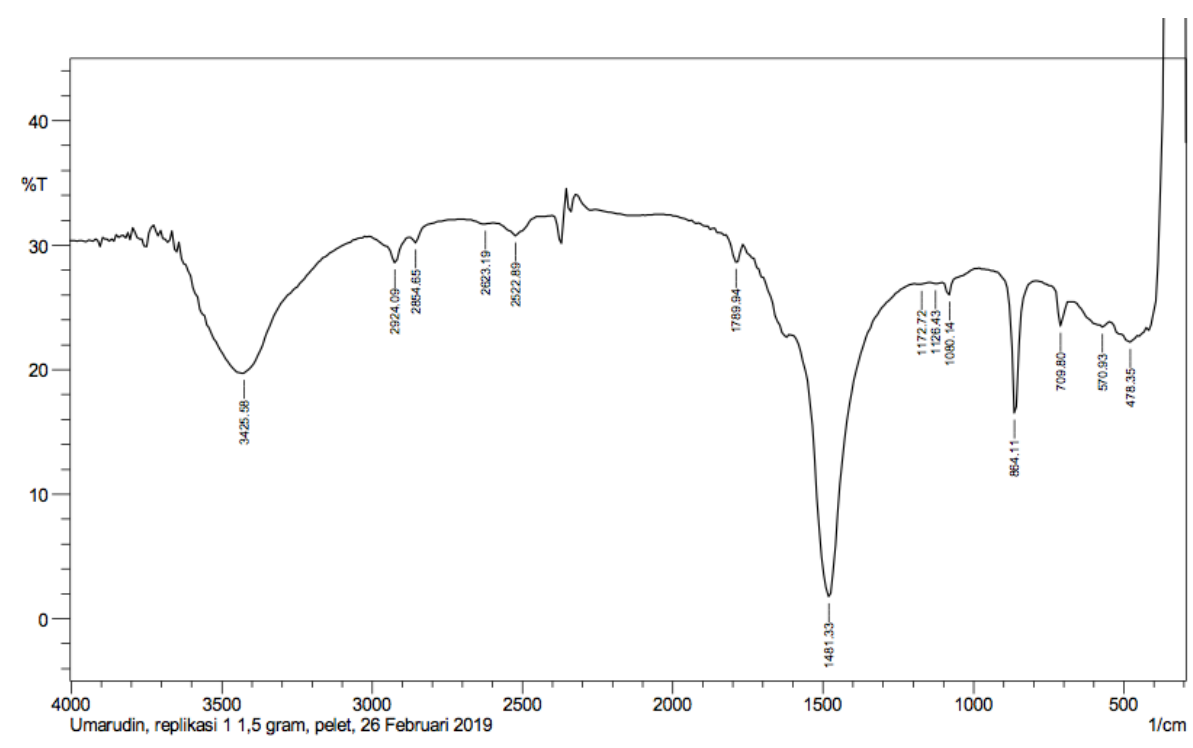

Figure 1. Results of FT-IR test for chitosan samples

The degree of deacetylation is one of the main parameters for chitosan characteristics. The degree of deacetylation of chitosan shows the low acetyl group on chitosan so that interactions between ions and hydrogen bonds in chitosan molecules will be stronger (Knorr, 1982). The higher the DD value, the better the quality of the chitosan. Polymers that have DD $>60 \%$ are called chitosan, while those with $<60 \%$ DD are called chitin (Czechowska-Biskup et al, 2012). Another opinion was delivered by Brugnerotto et al (2001) in Duarte et al (2002) that polymers that have DD $>50 \%$ are called chitosan while those $<50 \%$ are called chitin. The deacetylation degree from the sample of snail shell (Achatina fulica) chitosan obtained from this study is 63.09percent. DD results that are not too high are caused by a less than optimal deacetylation reaction so that there is still chitin which has not been transformed into chitosan. The difference in chitin and chitosan structure can be seen in Figure 2 below: 


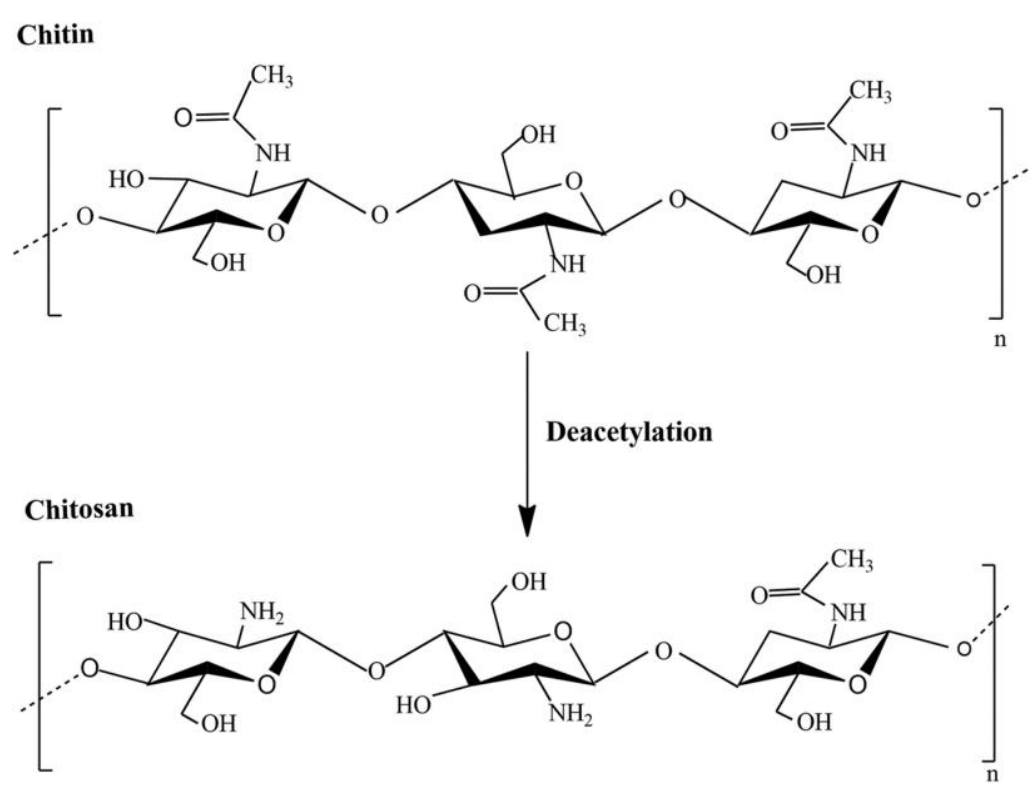

Figure 2. Chemical Structure of Chitin and Chitosan (Khattak et al, 2019)

Based on Figure 1 it can be seen that chitin molecules have acetyl (CH3-CO-) groups and secondary amide groups $(-\mathrm{NH})$, but when experiencing a deacetylation reaction chitin molecule will transform into chitosan which has a primary amide group $\left(-\mathrm{NH}_{2}\right)$. The FTIR results obtained from chitosan powder of snail shells (Achatina fulica) from the results of the study shows the presence of acetyl groups and primary amide groups. Thus, it is proven that the chitosan powder from the research results still contain chitin so that the DD obtained is also not too high.

The results of the process of distillation of the snail shell Chitosan continued dilution using a solution of $1 \%$ acetate acid as ingredients to dissolve the Chitosan. Acetate, $1 \%$ acid, is used to dissolve the soluble Chitosan because, in most organic acid solution at $\mathrm{pH}$ of about 4.0, it is not soluble in water, alcohol, solvents, and acetone (Sugita, 2009). The research is supported by Zahirudin et al. (2008), which proves that Chitosan can be soluble in acid concentration acetate. According to Dunn et al. (1997), the solubility of chitosan is closely related to the degree of deacetylation. Deacetylation will cut the acetyl group in chitin, which will leave the amine group. The presence of $\mathrm{H}^{+}$ ions in the amine will facilitate interaction with water molecules through hydrogen bonds. But chitosan cannot dissolve in water unless there is a substitution reaction. Both can dissolve in dilute acid solvents, such as acetic acid. The presence of a carboxyl group in acetic acid will facilitate the dissolution of chitin and chitosan because there is hydrogen interaction between the carboxyl group and the amine group from both (Dunn et al., 1997). Staphylococcus aureus bacteria which are added with snail shell chitosan with dose and incubation time for one day ( 24 hours), obtained the average seen in Table 1 below. 
Table I. Test results shell of snail chitosan activity against Staphylococcus aureus.

\begin{tabular}{llcc}
\hline No & \multicolumn{1}{c}{ Concentration } & $\begin{array}{c}\text { Average Inhibition Zone Clear } \\
\text { Diameter (mm) }\end{array}$ & $\begin{array}{c}\text { Deviation } \\
\text { standard }\end{array}$ \\
\hline 1 & $300 \mathrm{ppm}$ & 18.16 & 4.36845 \\
2 & $400 \mathrm{ppm}$ & 19.33 & 9.01850 \\
3 & $500 \mathrm{ppm}$ & 34.33 & 5.56776 \\
4 & $600 \mathrm{ppm}$ & 35.33 & 10.11599 \\
5 & $700 \mathrm{ppm}$ & 35.67 & 2.00000 \\
6 & Control (+): Ampicillin & 8.00 & - \\
7 & Control (-): Aquadest & 6.00 & - \\
\hline
\end{tabular}

In Table 1, it can be seen that the largest inhibition zone is at the concentration of $700 \mathrm{ppm}$ and the lowest at a concentration of $300 \mathrm{ppm}$, followed by a one-way ANOVA test, indicating that the administration of snail shell chitosan has a significant effect on the inhibition zone. Therefore, it is necessary to be tested further with the LSD test, the results of which are shown in Table II below.

Table II. The results of further testing of inhibitory zone LSD at each concentration shell of snail chitosan.

\begin{tabular}{ccc}
\hline No & Concentration & Value \\
\hline 1 & $300 \mathrm{ppm}$ & $18.16^{\mathrm{b}}$ \\
2 & $400 \mathrm{ppm}$ & $19.33^{\mathrm{b}}$ \\
3 & $500 \mathrm{ppm}$ & $34.33^{\mathrm{a}}$ \\
4 & $600 \mathrm{ppm}$ & $35.33^{\mathrm{a}}$ \\
5 & $700 \mathrm{ppm}$ & $35.67^{\mathrm{a}}$ \\
6 & Control (+): Ampicillin & $8.00^{\mathrm{c}}$ \\
7 & Control (-): Aquadest & $6.00^{\mathrm{c}}$ \\
\hline \multicolumn{2}{l}{ The numbers followed by the same letters in one row do not show a significant difference based on the LSD test at the } \\
95\% confidence level
\end{tabular}

One-way ANOVA test results showed that snail shell chitosan had a significant effect on the inhibition zone seen in Table II both at concentrations of $300 \mathrm{ppm}$ and 400 ppm, significantly different from concentrations of $500 \mathrm{ppm}, 600 \mathrm{ppm}$, and $700 \mathrm{ppm}$. The inhibition snail of shell chitosan at various concentrations are higher than control $(+)$ ampicillin and control (-) aquadest. This is likely due to the snail chitosan being able to inhibit the Staphylococcus aureus bacteria. According to Liu Hui et al. (2004), chitosan has antibacterial activity by killing bacteria and damaging bacterial cell membranes. Besides, chitosan contained in the snail shell is considered to be able to inhibit the growth of Staphylococcus aureus bacteria.

The LSD test results show that the inhibition power of snail shell chitosan extract at a concentration of $300 \mathrm{ppm}$ and $400 \mathrm{ppm}$ was significantly different from the concentrations of $500 \mathrm{ppm}, 600 \mathrm{ppm}$, and $700 \mathrm{ppm}$, while the concentrations of 500 ppm and $600 \mathrm{ppm}$ were not significantly different from $700 \mathrm{ppm}$. The concentration of snail shell chitosan extract was able to inhibit the growth of Staphylococcus aureus 
bacteria. This shows that it had a positive effect on inhibiting and killing Staphylococcus aureus (bacterized) bacteria. Bacteria are antibiotic properties that can kill bacteria (Mims et al., 2004).

Based on the results of the LSD test, the most optimum concentration was 500 ppm, it was able to inhibit the Staphylococcus aureus bacteria with an inhibitory power of $34.33 \mathrm{~mm}$. The inhibiting mechanism of snail shell chitosan extract, according to Killay (2013), is that chitosan has a functional group of amines that can form bonds with bacterial cell walls and can lead to leakage of intracellular constituents so that the bacteria will cause lysis. Chitosan performs intracellular binding, blocks mRNA, and inhibits protein synthesis. In addition, it is also supported by Helander et al. (2001), who states that the presence of a positive charge of NH3 + groups (amines) on chitosan can interact with negative charges on the surface of bacterial cells. So that it can result in weakening the strength of the cell wall, the shape of the cell wall becomes abnormal, and the pores of the cell wall will enlarge. This results in the cell wall not being able to regulate the exchange of substances from and into cells, then the cell membrane becomes damaged and will experience lysis which results in metabolic activity will be hampered and eventually will die.

The comparison used in this study was to use antibiotics. The antibiotic is used as positive control is Ampicillin. Ampicillin is a penicillin class antibiotic that can be used to treat Gram-positive and Gram-negative bacterial infections. The results of Brerner's (2011) show that the diffusion test using ampicillin antibiotics can inhibit the growth of Staphylococcus aureus bacteria with a diameter of the inhibition zone of $14 \mathrm{~mm}$. The mechanism of ampicillin in inhibiting Staphylococcus aureus bacteria inhibits bacterial cell wall synthesis by binding to one or more penicillin protein bonds (penicillin-binding protein) and can cause the final stages of transpeptidase synthesis to peptidoglycan synthesis on bacterial cell walls (Pratiwi, 2008).

Comparator as control (-) used 1\% acetate acid solvent. The results show a drag zone of $6 \mathrm{~mm}$. According to the table "Disc diffusion supplemental tables," Performance standards for antimicrobial susceptibility testing obtained from the Clinical and Laboratory Standards Institute (CLSI) results were resistant. Resistance is not disrupted by microbial cells by antibiotics, which is a natural mechanism for survival, it occurs when antibiotics are given or used with doses that are too low or improper treatment period (Tjay \& Rahardja, 2007). The most optimal concentration to be used as an antibacterial snail shell chitosan extract was $500 \mathrm{ppm}$ with an inhibition zone of 34.33 $\mathrm{mm}$, it means that the shellfish of snail shells was sensitive to the Staphylococcus aureus bacteria. Sensitive is a condition in which microbes are susceptible to antibiotics and are still good at providing resistance to microbes (Djide, 2008). The activity of snail shell chitosan has antibacterial properties to the Staphylococcus aureus bacteria. On the other hand, it is useful as an anti-acne, edible and antimicrobial coatings, antifungal, and surgical threads. Therefore, snail shell chitosan extracts have the opportunity to be utilized in the world of health, food, and industry. 


\section{Conclusion}

The deacetylation degree of chitosan that prepared by the shell snail is $63.09 \%$. Chitosan has an antibacterial activity of Staphylococcus aureus, so it can be used to an antibacterial agent. The optimum concentration of chitosan that can inhibit Staphylococcus aureus growth is $500 \mathrm{ppm}$.

\section{References}

Bannister, B., S. Gillespie \& J. Jones. 2006. Infection: Microbiology and Management, 3rd edition. Massachusetts: Blackwell Publishing, Ltd.

Biskup, RC., Jarosinska, D., Rokita, B., Ulanski, P., Rosiak, JM., 2012, Determination of Degree of Deacetylation of Chitosan-Comparison of Methods, Progress on Chemistry and Application of Chitin. 5 (6): 40-50.

Brugnerotto, J., Lizardi, J., Goyoolea, F., Arguelles-Monal, W., Desbrieres, J., \& Rinaudo, M., 2001. An infrared investigation in relation with chitin and chitosan characterization. Polymer 42: 3569-3580.

Duarte, M., Ferreira, M., Marväo, M., \& Rocha, J., 2002. An optimized method to determine the degree of acetylation of chitin and chitosan by FTIR spectroscopy. Int J Biol Macromol 31: 1-8.

Fletcher, D. L., 2007. Poultry meat quality. World's Poultry Science Journal / Volume 58 / Issue 02 / June 2002, pp 131-145 http://journals. cambridge.org/action/display Abstract;jsessionid=0E2CDF1DB39FEA0DCB38572246F85082.journals?fromPage= online\&aid $=622892$.

Goy, R. C., T.B. Morais, S., \& Assis, O. B. 2015. Evaluation of antimicrobial activity of chitosan and its quaternized derivative on Escherichia coli and Staphylococcus aureus Growth. Elsevier, 26: 122-127.

Helander, Lassila, N., Ahvenainen, R., J. Rhoades, \& S. Roller., 2001. Chitosan disrupts the barrier properties of the outer membrane of Gram-negative bacteria. International Jurnal of Food Microbiology, 71: 235-244.

Hogg, S. 2013. Essential Microbiology, 2nd edition. West Sussex: John Wiley \& Sons, Ltd.

Islam, M. M., Masum, S. M., Mahbub, K. R., \& Haque, A. M. 2011. Antibacterial istepietivity of Crab Chitosan against Staphylococcus aureus and Escherichia coli. Scien istepiSage, 2(4): 63-66. 
Khattak, S., Wahid, F., Liu, LP., Jia, SR., Chu, LQ., Xie, YY., Li, ZX., Zhong, C., 2019, Applications of Cellulose and Chitin/Chitosan Derivatives and Composites as Antibacterial Materials: Current State and Perspectives, Applied Microbiology and Biotechnology, 103 (5): 1989-2006.

Killay, A., 2013. Chitosan as an Antibacterial in Safe and Harmless Food Materials (Review): 200-205.

Knorr, D., 1982, Function Properties Chitin and Chitosan, Journal Food Science, 48, 36-41.

Komariah, A., 2014. Effectiveness of Nano Chitosan Antibacterial on the Growth of Staphylococcus aureus (In Vitro). 8: 371-377.

Kusumaningsih, T., Masykur, A., Arief, \& Usman. 2004. Making Chitosan from Chitin Snail Shell (Achatina fulica). Biofarmasi, 2(2): 64-68.

Liu, H., Du, Y., Wang, X., \& Sun, L. 2004. Chitosan kills bacteria through cell membrane damage. Elsevier, 95: 147-155.

Liu, N., Chen, X. G., Jin, P. H., Liu, C. G., Liu, C. S., \& Meng, X. H. 2006. Effect of MW and concentration of chitosan on antibacterial activity of Escherichia coli. Elsevier, 64: 60-65.

Mims C, Playfair J, \& Roitt I,. 2004. Medical microbiology. 3rded. London: Mosby International; p. 474-511.

Pratiwi, S.T. 2005. Pharmaceutical microbiology. Yogyakarta: Erlangga.

Rahmadani \& Susanti, D., 2011. Utilization of Chitosan from Snail Shell Waste as Copper Metal Adsorban, Research Journal, Medan State University.

Salami, L., 1998. Utilization of Chitosan from Waste Selection of Method of Isolation of Chitin and Extraction of Chitosan from Phenaus monodon and Its Application as Coagulation Material of Textile Industry Liquid Waste. [Essay]. Jakarta: Chemistry Department FMIPA UI.

Sugita, P., 2009. Chitosan: Source of Future Biomaterials. IPB Press: Bogor.

Tjay, T. H, \& Kirana R. 2007. Important Medicines Efficacy, Use and Side Effects, Sixth Edition, 262, 269-271, PT. Elex Media Komputindo, Jakarta.

Tortora, G.J., B.R. Funke \& C.L. Case. 2013. Microbiology an Introduction, 11th edition. New York: Pearson Education, Inc.

Zahirudin, Z., Ariesta, A., \& Salamah, E. 2008. Quality and Solubility Characteristics of Chitosan from Silage Dregs of Wind Shrimp Head (Penaeus monodon). Fishery Product Technology Bulletin, 11 (2). IPB. 